\title{
Influence of Spacing and Dates of Sowing on Performance of Castor Hybrids in Rainfed Areas of Chitradurga
}

\author{
C. Umesha ${ }^{1 *}$, C.J. Sridhara ${ }^{1}$, N.S. Mavarkar ${ }^{1}$, A.H. Kumar Naik ${ }^{2}$, \\ D. Chandrappa ${ }^{2}$ and K.T. Gurumurthy ${ }^{3}$
}

${ }^{1}$ Department of Agronomy, College of Agriculture, Shivamogga, University of Agricultural and Horticultural Sciences, Shivamogga, India

${ }^{2}$ Zonal Agricultural Research Station, Babbur Farm, Hiriyur, University of Agricultural and Horticultural Sciences, Shivamogga, India

${ }^{3}$ Department of Soil Science and Agriculture Chemistry, University of Agricultural and Horticultural Sciences, Shivamogga, India

*Corresponding author

\section{A B S T R A C T}

Castor (Ricinus communis L.) is one of the oldest and most important non edible oil crops as main crop. This study was carried out to determine the effects of different inter- and intra-row spacings on the yield and yield components on Castor crop; was carried out at

Keywords

Spacing, Hybrids and number of capsules

Article Info

Accepted:

06 August 2018

Available Online:

10 September 2018 Babbur farm, ZAHRS, Hiriyur, Chitradurga, University of Agricultural and Horticultural Sciences, Shivamogga, Karnataka, during the growing season 2016 which comes under Central Dry Zone of Karnataka. Castor hybrids selected for the present study were DCH177, DCH-519 and HCH-6. The field experiment was set up in a factorial RCBD and row spacings $(90$ and $120 \mathrm{~cm}$ ) and intra-row spacing $(60 \mathrm{~cm})$ with two dates of sowing (June second fortnight and July second fortnight) were assigned in the plots. Number of branches, number of spikes, number of capsules spike ${ }^{-1}$ and seed yield were investigated. In general, wider inter row spacings and intra-row spacings, resulted in decreased seed yield. Significantly highest number of branches, number of spikes and number of capsules spike $^{-1}(8.95,6.66,84.38$, respectively) were obtained from 120 x $60 \mathrm{~cm}$ but significantly higher seed yield was noticed in $90 \times 60 \mathrm{~cm}\left(1487.56 \mathrm{~kg} \mathrm{ha}^{-1}\right)$ and plant density while the lowest number of branches, number of spikes and number of capsules $\operatorname{spike}^{-1}(8.23,5.80$ and 844.38, respectively) were recorded from $90 \times 60 \mathrm{~cm}$ plant density except seed yield significantly lowest was found in $120 \times 60 \mathrm{~cm}\left(1311.90 \mathrm{~kg} \mathrm{ha}^{-1}\right)$.

\section{Introduction}

It is most important oil seed crop of India due to fact that its oil has diversified uses and has great value in foreign trade. Unfortunately in India, castor along with other oilseed crops are raised under limited resources condition which leaving the crop thirsty and hungry by the resource poor farmers. However, castor is long duration, widely spaced crop with comparatively thin plant population as compared to other oil seed crops, provide ample scope for nutrient management practices to enhance the growth and yield of 
hybrid castor, although it's one of the important crop growing in the area of Chitradurga, become the castor cultivating tracts inherently blessed with meager amount of rainfall coupled with poor soil resources base, where rest of crops not be grown economically under such situations castor being is one of the promising option for the poor and marginal farmers. Globally castor is cultivated in more than 29 countries over an area of 14.48 lakh ha during 2015 with a production of 19.48 lakh tonnes and productivity of $1346 \mathrm{~kg} \mathrm{ha}^{-1}$. India has the largest area (11.48 lakh ha) and highest productivity (1666 $\mathrm{kg} \mathrm{ha}^{-1}$ ) in the world. Although Karnataka holds very less in terms of area (0.25 lakh ha), production (0.26 tonnes) but productivity of castor is quite low in Karnataka (685 $\mathrm{kg} \mathrm{ha}^{-1}$ ) as comparable to leading states like Gujarat (1988 $\left.\mathrm{kg} \mathrm{ha}^{-1}\right)$ and Rajasthan (1530 kg ha ${ }^{-1}$ ). (Anon., 2015). Optimizing planting population is an inexpensive practice that can significantly increase castor seed yield. However, the optimum plant population varies influenced by the genotype, environmental conditions, and agricultural practices. Because environmental conditions are not constant, there is not an individual plant density that can be broadly recommended for castor. Instead, we should focus on determining a range of plant populations targeting the best yield across years and environmental conditions. However, the productivity experienced by the farmers of this region is significantly lower, thus selection of potent hybrid and proper planting, geometry plays a major role and hence with that intention field experiment was planned in this area to transfer the growing technique for higher productivity of castor in the study area in the nutshell.

\section{Materials and Methods}

Field experiment was carried out at Babbur farm, ZAHRS, Hiriyur, Chitradurga,
University of Agricultural and Horticultural Sciences, Shivamogga, Karnataka, during the growing season 2016 which comes under Central Dry Zone of Karnataka, located at $13.95^{\circ}$ North latitude, $76.62^{\circ} 76.62^{\circ}$ East longitude with an altitude of $630 \mathrm{~m}$ (2066 feet) above mean sea level. Composite soil sample were collected during the two cropping seasons to determine physicochemical properties of the soil on the experimental site were clayey, slightly alkaline in $\mathrm{pH}$ (8.05) with an electrical conductivity of $0.97 \mathrm{dS} \mathrm{m}^{-1}$. The alkalinity was corrected by application of gypsum at the rate of $2 \mathrm{q} \mathrm{ha}^{-1}$ to bring soil to neutral condition before sowing. The soil was low in organic carbon $(0.14 \%)$, medium in available nitrogen $\left(274 \mathrm{~N} \mathrm{ha}^{-1}\right)$, medium in available phosphorus (41 $\mathrm{kg} \mathrm{P} \mathrm{ha}^{-1}$ ) and available potassium $317 \mathrm{~kg} \mathrm{~K} \mathrm{ha}^{-1}$ ). The Castor (Ricinus communis L.) hybrids selected for the present study were DCH-177, DCH519 and HCH-6. Seeds of the hybrids were sown in two spacings of $90 \times 60 \mathrm{~cm}$ and 120 $\mathrm{X} 60 \mathrm{~cm}$ allocating 12 treatments in three replications and the treatments were laid out in a factorial RCBD. The seed were sowed on second fortnight June 2016 and second fortnight July 2016. Seeds were sown in manually and recommended dose of NPK was applied according to Agronomic recommendations. Data collected include number of branches, number of spikes, number of capsules spike ${ }^{-1}$ and seed yield ( $\mathrm{kg}$ $\mathrm{ha}^{-1}$ ).

\section{Results and Discussion}

The data pertaining to number of branches, number of spikes, number of capsules spike ${ }^{-1}$ and Seed yield $\left(\mathrm{kg} \mathrm{ha}{ }^{-1}\right)$ as influenced by different hybrids, spacings and date of sowing of castor at harvest are presented in Table 1. During harvest, significantly higher number of branches was recorded in the DCH- 519 (10.55) over DCH-177 (9.06) and significantly lowest number of branches was recorded in 
HCH - 6 (7.23). Among the spacing tested, $120 \times 60 \mathrm{~cm}$ recorded higher number of branches (8.95) which was on par with $90 \times$ $60 \mathrm{~cm}$ spacing (8.23). Significantly higher number of branches recorded in June second fortnight (9.28) and significantly lower number of branches was recorded in the July second FN (7.95). DCH- 177 was recorded significantly highest total number of number of spikes (6.91) over DCH- 519 hybrid (6.50) and significantly lower number of spikes plant $^{-1}$ recorded in HCH-6 (5.28). $120 \times 60 \mathrm{~cm}$ recorded significantly higher number of spikes (6.66) as compared to $90 \times 60 \mathrm{~cm}(5.80)$. Among the dates of sowing June second fortnight recorded significantly higher number of spikes (6.77) over June second fortnight (5.69).

Table.1 Number of branches, number of spikes, number of capsules spike ${ }^{-1}$ and seed yield (kg $\mathrm{ha}^{-1}$ ) as influenced by different hybrids, spacings and date of sowing of castor

\begin{tabular}{|c|c|c|c|c|}
\hline Treatments & $\begin{array}{c}\text { Number of } \\
\text { branches }\end{array}$ & $\begin{array}{l}\text { Number of } \\
\text { spikes }\end{array}$ & $\begin{array}{c}\text { Number of } \\
\text { capsules spike }\end{array}$ & Seed yield $\left(\mathrm{kg} \mathrm{ha}^{-1}\right)$ \\
\hline \multicolumn{5}{|l|}{ Hybrids (H) } \\
\hline $\mathrm{H}_{1}$ & 9.06 & 6.91 & 90.13 & 1603.49 \\
\hline $\mathrm{H}_{2}$ & 10.55 & 6.50 & 79.52 & 1570.03 \\
\hline $\mathrm{H}_{3}$ & 7.23 & 5.28 & 69.78 & 1025.66 \\
\hline S. Em \pm & 0.22 & 0.18 & 2.23 & 67.98 \\
\hline CD at $5 \%$ & 0.64 & 0.54 & 6.55 & 199.43 \\
\hline \multicolumn{5}{|l|}{ Spacing (S) } \\
\hline$S_{1}$ & 8.23 & 5.80 & 75.24 & 1487.56 \\
\hline$S_{2}$ & 8.95 & 6.66 & 84.38 & 1311.90 \\
\hline S. Em \pm & 0.18 & 0.15 & 1.82 & 55.51 \\
\hline CD at $5 \%$ & 0.52 & 0.44 & 5.35 & 162.84 \\
\hline \multicolumn{5}{|c|}{ Dates of sowing (D) } \\
\hline$D_{1}$ & 9.28 & 6.77 & 86.61 & 1465.49 \\
\hline$D_{2}$ & 7.95 & 5.69 & 73.01 & 1302.56 \\
\hline S. Em \pm & 0.18 & 0.15 & 1.82 & 115.51 \\
\hline CD at $5 \%$ & 0.52 & 0.44 & 5.35 & 162.84 \\
\hline
\end{tabular}

$\mathrm{H}_{1}$ : DCH -177, $\mathrm{H}_{2}$ : DCH -519, $\mathrm{H}_{3}: \mathrm{HCH}-6, \mathrm{~S}_{1}: 90 \times 60 \mathrm{~cm}, \mathrm{~S}_{2}: 120 \times 60 \mathrm{~cm}, \mathrm{D}_{1}$ : June Second FN, $\mathrm{D}_{2}$ : July Second FN

Total number of capsules per plant was significantly higher in the DCH-177 (90.13) as compared to DCH-519 (79.52) and significantly lower total number of capsules per plant HCH-6 (69.78). $120 \times 60 \mathrm{~cm}$ recorded significantly higher number of capsule (84.38) as compared to $90 \times 60 \mathrm{~cm}$ (75.24). Sowing in the month of June second fortnight significantly higher number of capsules spike ${ }^{-1}$ (86.61) than July second fortnight sowing (73.01). Seed yield varied significantly due to castor hybrids, DCH-177 was recorded significantly higher seed yield $\left(1603.49 \mathrm{~kg} \mathrm{ha}^{-1}\right)$ which was on par with DCH-519 (1570.03 kg ha $\left.{ }^{-1}\right)$ and significantly lower seed yield was recorded in $\mathrm{HCH}-6$ $\left(1025.66 \mathrm{~kg} \mathrm{ha}^{-1}\right)$. Spacing of $90 \times 60 \mathrm{~cm}$ recorded significantly higher seed yield $\left(1487.56 \mathrm{~kg} \mathrm{ha}^{-1}\right)$ over $120 \times 60 \mathrm{~cm}(1311.90$ $\left.\mathrm{kg} \mathrm{ha}^{-1}\right)$. Among dates of sowing, seed yield was significantly higher in the June second fortnight (1465.49 $\left.\mathrm{kg} \mathrm{ha}^{-1}\right)$ as compared to 
July second fortnight (1302.56 $\left.\mathrm{kg} \mathrm{ha}^{-1}\right)$. This might be due to favourable male and female flowers promoted lower yield components resulting in higher yield. Delay in sowing resulted in decrease of grain yield of 11.23 per cent when compared to sowing June second fortnight date due to the coincidence of flowering and capsule development with relatively low temperatures, which adversely affect the fertilization and low temperature prevailed during the vegetative growth to low plant stature and dry matter accumulation corresponding with quantity of assimilates diverted to sink, which results in lower number of capsules production. The reduction in yield due to delayed sowings are in conformity with Sudha Rani (2001), Sreedhar (2001), Nagabhushanam and Raghavaiah (2005) Reddy et al., (2007), Virender et al., (2008), Venkate gowda (2011), Lopes et al., 2014 and Reager et al., (2016).

\section{References}

Anonymous, 2015, Oilseeds Statistics, Compendium, ICAR-Indian Institute of Oilseeds Research, Hyderabad.

Lopes, G. E. M. Vieira, H. D. and Partelli, F. L., 2014, Evaluation of castor bean genotypes sown in winter and summer at a low altitude, Genetics and Mol. Res. 13(4): 8807-8814.

Nagabhushanam, U. and Raghavaiah, C. V., 2005, Seeding date and irrigation effects on the productivity and oil quality of post monsoon grown castor, Ricinus communis L. in Alfisols. J.Oilseeds Res., 22(1): 206-208.
Reager, M. L., Deora, N. S., Tak. S. R. and Sanwal, R. C., 2016, Effect of sowing date and plant spacing on growth, yield and quality of castor (Ricinus communis L.) in Transitional Luni Basin Plain Zone of Rajasthan, J. Progressive Agric., 7(1): 91-96.

Reddy, U. V. B., Reddy, G. P. and Reddy, D. S., 2007, Effect of seeding time on productivity of castor, Ricinus communis L. cultivars in southern agroclimatic zone of Andhra Pradesh. $J$. Oilseeds Res., 24(2): 280-282.

Sreedhar C., 2001, Influence seeding time on castor genotypes under irrigated conditions. M. Sc. (Ag). Thesis, Acharya N.G. Ranga Agricultural University, Hyderabad.

Sudha Rani, C., 2001, Crop growth and development of castor cultivars under optimal and sub-optimal water and nitrogen conditions in Telangana region. $P h$. $D$ Thesis submitted to Acharaya N. G. Ranga Agric. Uni., Hyderabad.

Venkatachalapathi, V., Gangadhare Rao and Rudramuni, T., 2016, Optimization of castor (Ricinus communis L.) production under limited resource conditions in central dry zone of Karnataka. Int. J. Appl. Pure Sci. Agric., 2(11): 1-3.

Virender S., Jayesh Singh and Bajaj, R. K., 2008, Investigation on sowing time, plant density and nutrient requirements of hybrid castor (Ricinus communis L.) for the non-traditional area of Punjab. $J$. Oilseeds Res., 25(1): 41-43.

\section{How to cite this article:}

Umesha, C., C.J. Sridhara, N.S. Mavarkar, A.H. Kumar Naik, D. Chandrappa and Gurumurthy, K.T. 2018. Influence of Spacing and Dates of Sowing on Performance of Castor Hybrids in Rainfed Areas of Chitradurga. Int.J.Curr.Microbiol.App.Sci. 7(09): 685-688. doi: https://doi.org/10.20546/ijcmas.2018.709.081 